\title{
NUTRIENT CONTENT OF BIOMASS COMPONENTS OF HAMLIN SWEET ORANGE TREES
}

\author{
Dirceu Mattos Jr. ${ }^{1 *}$; José Antônio Quaggio ${ }^{2,4}$; Heitor Cantarella ${ }^{2,4}$; Ashok Kumar Alva ${ }^{3}$ \\ ${ }^{1}$ Centro de Citricultura Sylvio Moreira - IAC, Rod. Anhanguera km 158 - CEP: 13490-970 - Cordeirópolis, SP. \\ ${ }^{2}$ Centro de Solos e Recursos Agroambientais - IAC, C.P. 28 - CEP: 13020-970 - Campinas, SP. \\ ${ }^{3}$ USDA-ARS, Vegetable and Forage Crop Research Unit, 24105 N Bunn Rd., Prosser, WA 99350. \\ ${ }^{4}$ Fellow CNPq. \\ *Corresponding author <ddm@centrodecitricultura.br>
}

\begin{abstract}
The knowledge of the nutrient distribution in trees is important to establish sound nutrient management programs for citrus production. Six-year-old Hamlin orange trees [Citrus sinensis (L.) Osb.] on Swingle citrumelo [Poncirus trifoliata (L.) Raf. x Citrus paradisi Macfad.] rootstock, grown on a sandy Entisol in Florida were harvested to investigate the macro and micronutrient distributions of biomass components. The biomass of aboveground components of the tree represented the largest proportion of the total. The distribution of the total tree dry weight was: fruit $=30.3 \%$, leaf $=9.7 \%$, twig $=26.1 \%$, trunk $=6.3 \%$, and root $=$ $27.8 \%$. Nutrient concentrations of recent mature leaves were in the adequate to optimal range as suggested by interpretation of leaf analysis in Florida. Concentrations of $\mathrm{Ca}$ in older leaves and woody tissues were much greater than those in the other parts of the tree. Concentrations of micronutrients were markedly greater in fibrous root as compared to woody roots. Calcium made up the greatest amount of nutrient in the citrus tree (273.8 $\mathrm{g}$ per tree), followed by $\mathrm{N}$ and $\mathrm{K}$ ( 234.7 and $181.5 \mathrm{~g}$ per tree, respectively). Other macronutrients comprised about $11 \%$ of the total nutrient content of trees. The contents of various nutrients in fruits were: $\mathrm{N}$ $=1.20, \mathrm{~K}=1.54, \mathrm{P}=0.18, \mathrm{Ca}=0.57, \mathrm{Mg}=0.12, \mathrm{~S}=0.09, \mathrm{~B}=1.63 \times 10^{-3}, \mathrm{Cu}=0.39 \times 10^{-3}, \mathrm{Fe}=2.1 \times 10^{3}$, $\mathrm{Mn}=0.3810^{-3}$, and $\mathrm{Zn}=0.4010^{-3}\left(\mathrm{~kg} \mathrm{ton}^{-1}\right)$. Total contents of $\mathrm{N}, \mathrm{K}$, and $\mathrm{P}$ in the orchard corresponded to $66.5,52.0$, and $8.3 \mathrm{~kg} \mathrm{ha}^{-1}$, respectively, which were equivalent to the amounts applied annually by fertilization. Key words: Citrus sinensis, mineral nutrition, dry matter, chemical analysis, nutrient distribution
\end{abstract}

\section{CONTEÚDO DE NUTRIENTESEM COMPONENTES DA BIOMASSA DE LARANJEIRA HAMLIN}

\begin{abstract}
RESUMO: A compreensão da distribuição de nutrientes na árvore é importante para o estabelecimento de programas de manejo nutricional eficientes para a produção de citros. Árvores de laranjeira Hamlin [Citrus sinensis (L.) Osb.] em citrumelo Swingle [Poncirus trifoliata (L.) Raf. x Citrus paradisi Macfad.], com 6 anos de idade, cultivadas num Entisol da Flórida foram colhidas para investigar a distribuição e o conteúdo de macro e micronutrientes em componentes da biomassa. A distribuição de nutrientes, em peso seco, da biomassa total da árvore foi: frutos $=30,3 \%$, folhas $=9,7 \%$, ramos $=26,1 \%$, tronco $=6,3 \%$ e raízes $=27,8 \%$. A concentração de nutrientes em folhas recém maduras ficou entre os níveis adequado e ótimo pela interpretação da análise foliar da Flórida. Maiores concentrações de Ca foram observadas nas folhas mais velhas e nos tecidos lenhosos. Concentrações de micronutrientes foram significativamente maiores nas radicelas em comparação àquelas lenhosas. O maior conteúdo de nutriente na árvore foi de $\mathrm{Ca}(273,8 \mathrm{~g} /$ árvore), seguido de $\mathrm{N}$ e de K (243,7 e 181,5 g/árvore, respectivamente). Outros macronutrientes somaram cerca de $11 \%$ do conteúdo total de nutrientes. O conteúdo de vários nutrientes na fruta fresca, em $\mathrm{kg} \mathrm{ton}^{-1}$, foi: $\mathrm{N}=1,20 ; \mathrm{K}=1,54 ; \mathrm{P}=0,18 ; \mathrm{Ca}=0,57 ; \mathrm{Mg}=0,12 ; \mathrm{S}=0,09 ; \mathrm{B}=1,63 \times 10^{-3} ; \mathrm{Cu}=0,39 \times 10^{-3} ; \mathrm{Fe}=2,1$ $\times 10^{-3} ; \mathrm{Mn}=0,38 \times 10^{-3}$ e $\mathrm{Zn}=0,40 \times 10^{3}$. O conteúdo total de $\mathrm{N}, \mathrm{K}$ e P no pomar correspondeu a $66,5,52,0$, and $8,3 \mathrm{~kg} \mathrm{ha}^{-1}$, respectivamente, os quais foram equivalentes às quantidades de nutriente aplicadas anualmente pela adubação.

Palavras-chave: Citrus sinensis, nutrição mineral, matéria seca, análise química, distribuição de nutrientes
\end{abstract}

\section{INTRODUCTION}

There is an increasing need to review information on crop nutrition for adequate establishment of nutrient requirements and fine-tuning rates of fertilizer used in agricultural systems because of the risks of adverse environmental impact of excess nutrient applications. This study, conducted in 1999, was part of an ongoing project on best management practices (BMPs) for citrus growing in Florida.
Smith (1966a) and Chapman (1968) discussed data on mineral composition of citrus trees published between the 1930's and the 1960's. These authors reported results of several chemical analyses of important components of citrus tree biomass, which allow a broad understanding of amounts, proportions, and distribution of nutrients in the various compartments of the plant. In Brazil, a comprehensive study on mineral composition of fruit (peel, pulp + juice, and seeds) of sweet oranges, acid lime, grapefruit, tangor, and mandarin was presented by 
Bataglia et al. (1977). Later work of Amorós Castañer (1995) and Jackson et al. (1995) also reported data on amounts of nutrients removed per ton of oranges and mandarins. There is an agreement that calcium, nitrogen, and potassium are the dominant constituents of citrus tree biomass. Phosphorus, magnesium, and sulfur represent a smaller proportion $(\sim 10 \%)$ followed by micronutrients $(<1 \%)$. However, the proportion of individual nutrients may vary among different cultivars, tree age, and horticultural practices in the orchard.

The removal of nutrient by plant biomass has been used as one of the components to estimate fertilizer requirements for annual grain crops. The same approach, on the basis of nutrient removal of fruits, is valid for establishing nutrient management programs for citrus trees; i.e. fertilizer recommendations for citrus in Brazil rely on fruit yield criteria (Quaggio et al., 1996). However, unlike the annual crops, in the case of citrus a large pool of nutrients present in the structural framework of trees represent a large storage which is carried from year to year, and provides nutrients for fruit production during deficiency of applied nutrients (Kato, 1986; Feigenbaum et al., 1987; Legaz et al., 1995).

In an attempt to tailor BMPs to specific production conditions, research has also focused on modeling biological processes to assess citrus nutrient requirement and to incorporate information into computer-based decision support expert systems (Bustan et al., 1999). Patterns of nutrient accumulation and removal by the crop are of great interest to modelers. The objective of this study was to determine the amount and distribution of nutrients in different parts of 6-year-old citrus trees.

\section{MATERIAL AND METHODS}

Six-year-old Hamlin orange trees [Citrus sinensis (L.) Osb.] on Swingle citrumelo rootstock [Poncirus trifoliata (L.) Raf. $x$ Citrus paradisi Macfad.] planted at 7.6 x $4.6 \mathrm{~m}$ spacing on a Candler fine sand (hyperthermic, uncoated Typic Quartzipsament) (National Cooperative Soil Service, 1990) along the Florida central ridge USA, were used in this study. This soil unit is deep well-drained sand (sand content of $967 \mathrm{~g} \mathrm{~kg}^{-1}$ ) with no confining horizons, low organic matter content, and low water holding capacity.

The experiment was a randomized design with three replications and a single tree assigned to each experimental plot. Trees were irrigated using under-thetree low volume emitters, using one emitter per tree covering about $7 \mathrm{~m}^{2}$ area under the tree canopy with a delivery rate of $50 \mathrm{~L} \mathrm{~h}^{-1}$. During the course of the experiment, irrigation was scheduled when available soil moisture content depleted by $33 \%$ in the top $40 \mathrm{~cm}$ depth soil, which represented the effective rooting depth of young citrus trees. Soil moisture content at various depths under the tree canopy was monitored using capacitance probes (Alva \& Fares, 1998; Fares \& Alva, 1999). The trees received annual application rates ( $\mathrm{g}$ per tree) of $\mathrm{N}$ $=230, \mathrm{P}=35$, and $\mathrm{K}=200$ (Ferguson et al., 1995) as ammonium nitrate, triple superphosphate, and potassium chloride, respectively. The fertilizers were split in three applications. Boron, zinc and manganese were applied by foliar spray using a solution prepared with soluble salts during the spring (Ferguson et al., 1995).

The trees were harvested in December 1999 for dry matter evaluation of different tree components and subsampled for determination of nutrient concentration as described by Mattos Jr. (2000). The aboveground portion of the tree was divided into: (i) summer/fall 1999 leaf flush (<6-month-old); (ii) spring 1999 + older leaves; the latter component was made up mostly by summer/ fall 1998 flushes; (iii) twigs $>1.5 \mathrm{~cm}$ in diameter; (iv) twigs $\leq 1.5 \mathrm{~cm}$ in diameter; (v) trunk; and (vi) fruit. Two opposing quadrants (NW and SE) of $1.75 \times 1.75 \mathrm{~m}$ each were marked on the soil surface, and which had the tree trunk in a common vertex. This procedure was taken in order to facilitate root collection, since it was assumed that root distribution was uniform among all soil quadrants. The soil was dug from each quadrant to $45 \mathrm{~cm}$ depth and sieved $(0.2 \mathrm{~cm}$ sieve) to collect the roots, which were separated into: (i) fibrous roots $<0.2 \mathrm{~cm}$ diameter; (ii) woody roots, 0.2 to $1.0 \mathrm{~cm}$ diameter; and (iii) woody roots $>1.0 \mathrm{~cm}$ diameter. The taproot was also separated from the soil.

Samples from each tree parts placed in sealed plastic bags to prevent water loss, and fresh weights were recorded. These samples were washed, and dried at $65^{\circ} \mathrm{C}$ for 72 hours and dry weight was recorded. Total dry weight of roots was estimated by multiplying the values obtained for both excavated soil quadrants by 2 . A subsample of dry matter from each tree part was ground to pass 40 mesh sieve and concentration of $\mathrm{N}$ was determined with an automated Roboprep $\mathrm{C} / \mathrm{N}$ analyzer (Europa Scientific LTD., England) by dry combustion (Mulvaney, 1993). Concentrations of $\mathrm{Ca}, \mathrm{Mg}, \mathrm{K}, \mathrm{Cu}, \mathrm{Fe}$, $\mathrm{Mn}, \mathrm{Zn}$ were determined by ICP spectrometry, and those of $\mathrm{P}, \mathrm{S}$, and $\mathrm{B}$ by UV-Vis spectrophotometry, after digestion of tissue with concentrate $\mathrm{HNO}_{3}+\mathrm{HClO}_{4}(2: 1 \mathrm{v} /$ $v$ ratio) (Bataglia et al., 1983).

Total nutrient content of tree biomass components was calculated by multiplying the dry matter of components by the respective nutrient concentration. An analysis of variance (ANOVA) was used to test the hypothesis that nutrient content of biomass components are equal $(P=0.05)$ using the GLM procedure of the SAS $®$ system (SAS Institute, 1996). The least significant difference (LSD; $P=0.05$ ) procedure was used for making pairwise comparisons among means of nutrient concentration and nutrient content of tree components.

\section{RESULTS AND DISCUSSION}

Characteristics of trees and biomass production are outlined here with data adapted from Mattos Jr. 
(2000). The mean height of the trees was $2.5 \pm 0.01 \mathrm{~m}$ with a canopy diameter of $2.5 \pm 0.14 \mathrm{~m}$. Trunk height was $41.4 \pm 3.9 \mathrm{~cm}$, and perimeter was $24.5 \pm 1.5 \mathrm{~cm}$, above the bud union. Table 1 shows that the dry matter in the aboveground parts of the tree represented $>70 \%$ of the total tree biomass. The largest proportion of total tree biomass was that of fruit, which represented $30 \%$. The average fruit yield was $15.04 \pm 0.11$ ton $\mathrm{ha}^{-1}$ (fresh weight basis). Leaves accounted for about 9.7 and roots accounted for $27.7 \%$ of the total dry weight of the tree. Fibrous roots accounted for the greatest proportion in the belowground portion (35.6\%) after the taproot $(38.4 \%)$. Our data are comparable to the values reported for citrus (Nadir, 1973; Dasberg, 1987; Feigenbaum et al., 1987; Alva et al., 1999), since $>70 \%$ of the total tree biomass was found on the aboveground portion. Deviations in the partitioning of the dry matter of various tree parts are attributed to differences in combination of scion and rootstock varieties, tree age, type of tree part sampled, fruit load and horticultural practices. Lea-Cox et al. (2001) observed that same age

Table 1 - Mean biomass distribution of 6-year-old Hamlin sweet orange tree on Swingle citrumelo rootstock grown in a sandy Entisol.

\begin{tabular}{lcc}
\hline \multirow{2}{*}{ Tree components } & \multicolumn{2}{c}{ Biomass distribution } \\
\cline { 2 - 3 } & Dry weight & Fresh weight \\
\hline & $\%$ of total tree biomass \\
Fruit & 30.3 & 59.3 \\
Leaf $<6$-month-old & 6.3 & 4.8 \\
Leaf $>6$-month-old & 3.4 & 2.4 \\
Twig $>15 \mathrm{~mm}$ diam. & 9.1 & 4.3 \\
Twig $<15 \mathrm{~mm}$ diam. & 17.0 & 8.7 \\
Trunk & 6.3 & 3.0 \\
Taproot & 10.7 & 4.7 \\
Fibrous roo & 9.9 & 8.8 \\
Woody root & 4.1 & 2.4 \\
Woody roo\$ & 3.1 & 1.7 \\
& \multicolumn{2}{c}{$\mathrm{kg}$ per tree } \\
Total & $25.0 \pm 0.5$ & $88.5 \pm 2.7$ \\
\hline
\end{tabular}

${ }^{\dagger}<0.2 \mathrm{~cm}$ diameter; ${ }^{\ddagger} 0.2-1.0 \mathrm{~cm}$ diameter; ${ }^{\S}>1.0 \mathrm{~cm}$ diameter.
Redblush grapefruit trees on Volkamer lemon were larger than trees on sour orange rootstock, and dry weight distribution of tree parts was affected by $N$ fertilization and soil condition. A competitive effect of fruit load on the dry weight allocation to the spring flush of these trees was also observed.

Concentration of macro and micronutrients in the leaves were within the range of optimal concentrations as suggested by the guidelines for interpretation of leaf analysis based on 4-to-6-month-old spring flush from nonfruiting terminals (Tables 2 and 3 ) (Hanlon et al., 1995). The Ca concentration was greater in the older flush (>6-month-old) leaves compared to that in the young flush (<6-month-old). A similar pattern was also observed for micronutrients concentrations. This trend agrees with that reported by Smith (1966b). Moreno \& Garcia-Martínez (1984) described the biochemical process of $\mathrm{N}$ mobilization in citrus trees (proteolysis), in which total protein content of old leaves decreased progressively from the beginning of February (spring flush) to June. Retranslocation of nutrients from mature to younger tissue occurs to a lesser extent for $\mathrm{Ca}$ and micronutrients compared to that for $\mathrm{N}, \mathrm{K}, \mathrm{P}$, and $\mathrm{Mg}$ (Marschner, 1995).

Nutrient concentrations were primarily lower in twigs, trunk, fruit, taproot, and root compared to leaves (Tables 2 and 3). Nutrients taken up by roots are primarily transported to the leaves, where most of the important biochemical reactions occurs, such as synthesis of carbohydrates and other organic compounds. This explains the observed differences in nutrient concentration. The nutrient concentrations are greater in the fibrous roots compared to those in the woody roots (Tables 2 and 3 ). Woody roots and older twigs presented the lowest levels of nutrient concentration $\left(<7.7 \mathrm{~g} \mathrm{~kg}^{-1}\right)$ among the root parts. Buildup of lignin and suberin in cell walls of older tissue restricts flow of phloem sap to such structural components and, therefore, hinders accumulation of nutrients. On the other hand, fibrous roots represent a functional tissue for nutrient uptake from

Table 2 - Macronutrient concentrations in dry matter from various parts of 6-year-old Hamlin sweet orange trees on Swingle citrumelo rootstock.

\begin{tabular}{|c|c|c|c|c|c|c|}
\hline Tree component & $\mathrm{N}$ & $\mathrm{K}$ & $\mathrm{P}$ & $\mathrm{Ca}$ & $\mathrm{Mg}$ & $\mathrm{S}$ \\
\hline & - & - & ---------- & n- & 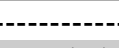 & -------- \\
\hline Leaf $<6$-month-old & $25.5^{(1.9)}$ & $13.8^{(1.4)}$ & $2.3^{(0.3)}$ & $36.8^{(3.7)}$ & $3.0^{(0.3)}$ & $2.3^{(0.1)}$ \\
\hline Leaf $>6$-month-old & $23.4^{(1.8)}$ & $10.3^{(1.0)}$ & $1.5^{(0.3)}$ & $46.5^{(3.0)}$ & $1.9^{(0.1)}$ & $3.1^{(0.2)}$ \\
\hline Twig $<1.5 \mathrm{~cm}$ diam. & $7.8^{(0.4)}$ & $4.1^{(0.5)}$ & $1.3^{(0.2)}$ & $16.7^{(0.4)}$ & $1.4^{(0.1)}$ & $0.8 \quad$ (\#) \\
\hline Twig $>1.5 \mathrm{~cm}$ diam. & $4.1^{(1.2)}$ & $2.9^{(0.8)}$ & $0.8^{(0.3)}$ & $8.5^{(0.9)}$ & $0.6^{(0.1)}$ & $0.4^{(0.1)}$ \\
\hline Trunk & $4.4^{(0.2)}$ & $3.1^{(0.3)}$ & $0.7 \quad$ (\#) & $5.4^{(0.8)}$ & $0.4^{(0.1)}$ & 0.4 (\#) \\
\hline Fruit & $8.3^{(0.3)}$ & $10.7^{(0.5)}$ & $1.3^{(0.1)}$ & $4.0^{(0.6)}$ & $0.8^{(0.1)}$ & $0.6^{(0.1)}$ \\
\hline Taproot & $3.8^{(0.3)}$ & $2.6^{(0.3)}$ & $0.4 \quad(\#)$ & $5.2^{(0.3)}$ & $0.3^{(0.1)}$ & $0.3 \quad(\#)$ \\
\hline Fibrous roo\# & $15.5^{(1.5)}$ & $9.9^{(1.5)}$ & $1.3^{(0.1)}$ & $8.7^{(1.0)}$ & $3.2^{(0.6)}$ & $2.5^{(0.4)}$ \\
\hline Woody roos & $7.7^{(0.8)}$ & $6.1^{(0.5)}$ & $1.1^{(0.1)}$ & $6.5^{(1.2)}$ & $0.9^{(0.1)}$ & $0.6^{(0.1)}$ \\
\hline Woody roof & $6.1^{(0.5)}$ & $4.4^{(1.2)}$ & $0.8^{(0.2)}$ & $6.7^{(1.0)}$ & $0.7^{(0.2)}$ & $0.5^{(0.1)}$ \\
\hline $\mathrm{LSD}_{0.05}$ & 0.6 & 0.5 & 0.1 & 1.0 & 0.1 & 0.5 \\
\hline
\end{tabular}

${ }^{\dagger}$ Numbers within parenthesis represent the standard error of the mean; ${ }^{\ddagger}<0.2 \mathrm{~cm}$ diameter; ${ }^{\S} 0.2-1.0 \mathrm{~cm}$ diameter; ${ }^{\natural}>1.0 \mathrm{~cm}$ diameter; \# Value $<0.1$. 
the soil, thus, contain higher nutrient concentration than those in the woody portion of roots or branches (Marschner, 1995). Differences were more accentuated for micronutrients than for macronutrients (Table 3). Average concentrations of micronutrients in the fibrous roots of Valencia orange grown in sand culture reported by Smith et al. (1954), $\left(\mathrm{mg} \mathrm{kg}^{-1}\right)$ were: $\mathrm{B}=25$; $\mathrm{Cu}=157$; $\mathrm{Fe}=1783 ; \mathrm{Mn}=257 ;$ and $\mathrm{Zn}=462$. These concentrations are similar to those reported in Table 3 , except for $\mathrm{Fe}$. Wutscher (1986) reported that concentration $\mathrm{Fe}$ in fibrous root of Hamlin orange trees in sandy soil was very low (201 $\left.\mathrm{mg} \mathrm{kg}^{-1}\right)$ compared to $\mathrm{Mn}$ and $\mathrm{Zn}\left(>1400 \mathrm{mg} \mathrm{kg}^{-1}\right)$. Such differences could be related to soil conditions and characteristics of citrus rootstocks to absorb nutrients.

The concentration of $\mathrm{K}$ in the fruit $\left(10.7 \mathrm{~g} \mathrm{~kg}^{-1}\right)$ was within the $\mathrm{K}$ concentration range for leaves, i.e., 10.3 to $13.8 \mathrm{~g} \mathrm{~kg}^{-1}$ (Table 2). This value is also comparable to the range of $\mathrm{K}$ concentration in the pulp + juice of fruit of orange varieties (9.0 to $13.4 \mathrm{~g} \mathrm{~kg}^{-1}$ ) reported by Bataglia et al. (1983).

Among the macronutrients in the tree, the content of $\mathrm{Ca}$ was the greatest (273.8 g per tree), followed by $\mathrm{N}$ and $\mathrm{K}$ (234.7 and $181.5 \mathrm{~g}$ per tree, respectively) (Figure 1). Other macronutrients ( $P, M g$, and S) comprised about $11 \%$ of total nutrient content in the trees. The pattern of nutrient distribution within tree biomass components was distinct, with greater amount of $\mathrm{Ca}$ being allocated in the framework structure of trees such as twigs. Nitrogen and $\mathrm{K}$ contents were markedly removed by the fruit component, which presented a $\mathrm{N}$ to $K$ ratio of $1: 1.28$, which compares with the value of 1:1.40 reported by Jackson et al. (1995). The total $P$ content was a small portion of nutrients stored in the trees (Figure 1) what is in accordance with data reported for non-bearing Hamlin orange trees in Florida (Alva et al., 1999). This correspondence occurs because of fruit did not represent a strong sink for absorbed $\mathrm{P}$. On the other hand, the proportion of $\mathrm{N}$ in the tree parts will greatly vary with fruit load (Lea-Cox et al., 2001). Macronutrients content of 19-year-old grapefruit trees presented by Chapman (1968) far exceeded our values because of the greater amount of total dry matter of trees $(273.15 \mathrm{~kg})$.

The total micronutrient content of the citrus tree was about $6 \mathrm{~g}$ (Table 4). The pattern of micronutrients distribution showed that greater amounts were found in the roots ( $>68 \%$ of total content) mainly because of higher concentration in fibrous roots (Table 3 ). A marked difference was observed for boron, as evident from 141 $\mathrm{mg} \mathrm{B}$ per tree in the fruits, versus $104 \mathrm{mg} \mathrm{B}$ per tree in all roots (Table 4). Woody tissue, represented by trunk,

Table 3 - Micronutrient concentrations in dry matter from various parts of 6-year-old Hamlin sweet orange trees on Swingle citrumelo rootstock.

\begin{tabular}{|c|c|c|c|c|c|}
\hline Tree component & $\mathrm{B}$ & $\mathrm{Cu}$ & $\mathrm{Fe}$ & $\mathrm{Mn}$ & $\mathrm{Zn}$ \\
\hline & \multicolumn{5}{|l|}{ 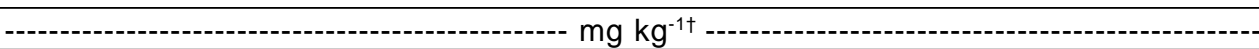 } \\
\hline Leaf $<6$-month-old & $54^{(13.0)}$ & $13^{(0.7)}$ & $71^{(5.6)}$ & $13^{(1.2)}$ & $14^{(1.6)}$ \\
\hline Leaf $>6$-month-old & $103^{(25.4)}$ & $22^{(2.0)}$ & $135^{(16.6)}$ & $28^{(4.8)}$ & $26^{(4.3)}$ \\
\hline Twig $<1.5 \mathrm{~cm}$ diam. & $17^{(1.2)}$ & $8^{(0.7)}$ & $35^{(2.3)}$ & $3^{(0.6)}$ & $14^{(0.6)}$ \\
\hline Twig $>1.5 \mathrm{~cm}$ diam. & $14^{(1.8)}$ & $4^{(0.6)}$ & $36^{(5.6)}$ & $2^{(\#)}$ & $12^{(1.4)}$ \\
\hline Trunk & $12^{(0.9)}$ & $6^{(2.2)}$ & $71(23.0)$ & $2^{(0.6)}$ & $29(7.3)$ \\
\hline Fruit & $19^{(1.7)}$ & $5^{(2.0)}$ & $28^{(2.1)}$ & $3^{(0.6)}$ & $6^{(1.2)}$ \\
\hline Taproot & $15^{(1.8)}$ & $4^{(0.4)}$ & $44^{(10.2)}$ & $2^{(\#)}$ & $21^{(5.4)}$ \\
\hline Fibrous roo\# & $29^{(6.3)}$ & $116^{(24.1)}$ & $536^{(104.6)}$ & $250^{(83.1)}$ & $409^{(104.0)}$ \\
\hline Woody roots & $17^{(3.1)}$ & $15^{(3.9)}$ & $99^{(32.7)}$ & $13^{(4.5)}$ & $65^{(22.2)}$ \\
\hline Woody roofl & $14^{(1.4)}$ & $8^{(5.6)}$ & $59^{(26.6)}$ & $5^{(3.1)}$ & $37^{(16.6)}$ \\
\hline $\mathrm{LSD}_{0.05}$ & 7 & 8 & 32 & 21 & 18 \\
\hline
\end{tabular}

${ }^{\dagger}$ Numbers within parenthesis represent the standard error of the mean; ${ }^{\ddagger}<0.2 \mathrm{~cm}$ diameter; ${ }^{\S} 0.2-1.0 \mathrm{~cm}$ diameter; ${ }^{\natural}>1.0 \mathrm{~cm}$ diameter; \# Value $<0.1$

Table 4 - Micronutrient contents in various parts of 6-year-old Hamlin sweet orange tree on Swingle citrumelo rootstock.

\begin{tabular}{|c|c|c|c|c|c|}
\hline Tree component & $\mathrm{B}$ & $\mathrm{Cu}$ & $\mathrm{Fe}$ & $\mathrm{Mn}$ & $\mathrm{Zn}$ \\
\hline Leaf $<6$-month-old & $85.8^{(23.3)}$ & $20.4^{(3.3)}$ & $\begin{array}{l}\text { mg per tre } \\
111.1^{(15.5)}\end{array}$ & $19.8^{(2.3)}$ & $21.2^{(3.4)}$ \\
\hline Leaf $>6$-month-old & $84.8^{(16.8)}$ & $19.1^{(3.5)}$ & $115.4^{(16.1)}$ & $24.1(10.2)$ & $22.4^{(6.7)}$ \\
\hline Twig $<1.5 \mathrm{~cm}$ diam. & $71.2^{(17.7)}$ & $34.0^{(8.7)}$ & $147.8^{(32.1)}$ & $11.5^{(3.9)}$ & $58.9^{(12.0)}$ \\
\hline Twig >1.5 cm diam. & $31.6^{(15.8)}$ & $9.7^{(3.5)}$ & $83.7^{(39.5)}$ & $4.5^{(1.8)}$ & $26.7^{(8.8)}$ \\
\hline Trunk & $18.3^{(2.2)}$ & $9.8^{(4.4)}$ & $114.2^{(66.0)}$ & $3.7^{(1.1)}$ & $46.1^{(20.6)}$ \\
\hline Fruit & $141.1^{(15.8)}$ & $40.7^{(7.5)}$ & $209.5^{(11.4)}$ & $20.2^{(4.5)}$ & $47.6^{(9.7)}$ \\
\hline Taproot & $39.8^{(8.5)}$ & $9.4^{(1.9)}$ & $111.0^{(7.1)}$ & $5.3^{(1.7)}$ & $53.7^{(0.9)}$ \\
\hline Roots & $108.1^{(42.2)}$ & $392.3^{(102.3)}$ & $1674.2^{(418.5)}$ & $848.8^{(353.8)}$ & $1127.0^{(457.3)}$ \\
\hline $\operatorname{LSD}_{0.05}$ & 12.7 & 17.6 & 146.3 & 72.8 & 119.5 \\
\hline
\end{tabular}

${ }^{\dagger}$ Numbers within parenthesis represent the standard error of the mean. 
twigs $>1.5 \mathrm{~cm}$ in diameter, and taproot, had lower amounts of $\mathrm{Mn}, \mathrm{Cu}$, and $\mathrm{Fe}$ than that in fruit, leaves and small twigs. This pattern was not observed for $\mathrm{Zn}$, which was rather evenly distributed, in the aboveground components of tree biomass.

Using the nutrient concentration measured in the fruits in this study, total nutrient contents per ton of fresh fruit were calculated and the data show $\left(\mathrm{kg} \mathrm{ton}^{-1}\right): \mathrm{N}=$ $1.20 ; \mathrm{K}=1.54 ; \mathrm{P}=0.18 ; \mathrm{Ca}=0.57 ; \mathrm{Mg}=0.12 ; \mathrm{S}=0.09$; $\mathrm{B}=1.63 \times 10^{-3} ; \mathrm{Cu}=0.39 \times 10^{-3} ; \mathrm{Fe}=2.1 \times 10^{-3} ; \mathrm{Mn}=$ $0.38 \times 10^{-3}$ and $\mathrm{Zn}=0.40 \times 10^{-3}$.

The content of macronutrients in the citrus orchard, as per area basis, decreased in the order: $\mathrm{Ca}>\mathrm{N}>\mathrm{K}>\mathrm{Mg}>\mathrm{P}>\mathrm{S}$ (Table 5). Total content of N, K, and $P$ in the orchard was equivalent to the amounts applied annually by fertilization. However, this relationship

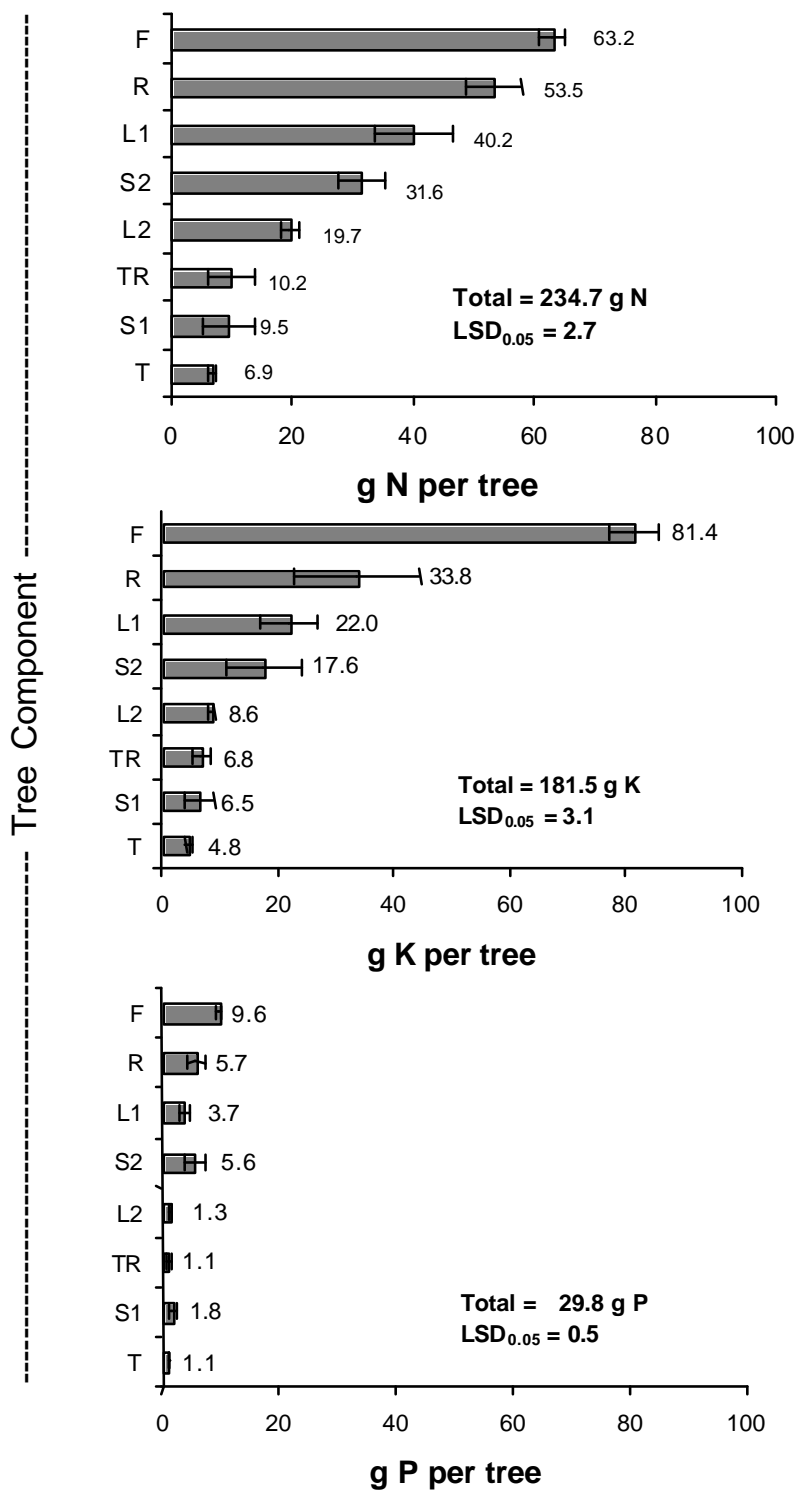

cannot be understood as high fertilizer use efficiency because of assimilation of nutrients occurs from the soiltree system on an annual basis. For example, the ${ }^{15} \mathrm{~N}$ recovery in the whole citrus tree of applied labeled $\mathrm{N}$ fertilizers during the spring summed up to $40 \%$ (Mattos Jr., 2000). Table 4 also shows that nutrient export by fruits, on the basis of whole tree nutrient content, agrees with data reported by Nadir (1973) for 20-year-old Valencia orange trees, and which results were $\mathrm{N}=20 \%$, $\mathrm{K}=40 \%$, and $\mathrm{P}=30 \%$.

The $\mathrm{Ca}$ to $\mathrm{Mg}$ ratio greatly varied among tree components (4.6:1 to 24.3:1) (Table 5), while the soil analysis revealed a 5.6:1 ratio (data not shown). This pattern demonstrates the contrasting accumulation of nutrient in the tree components according to the demand of each tissue part.

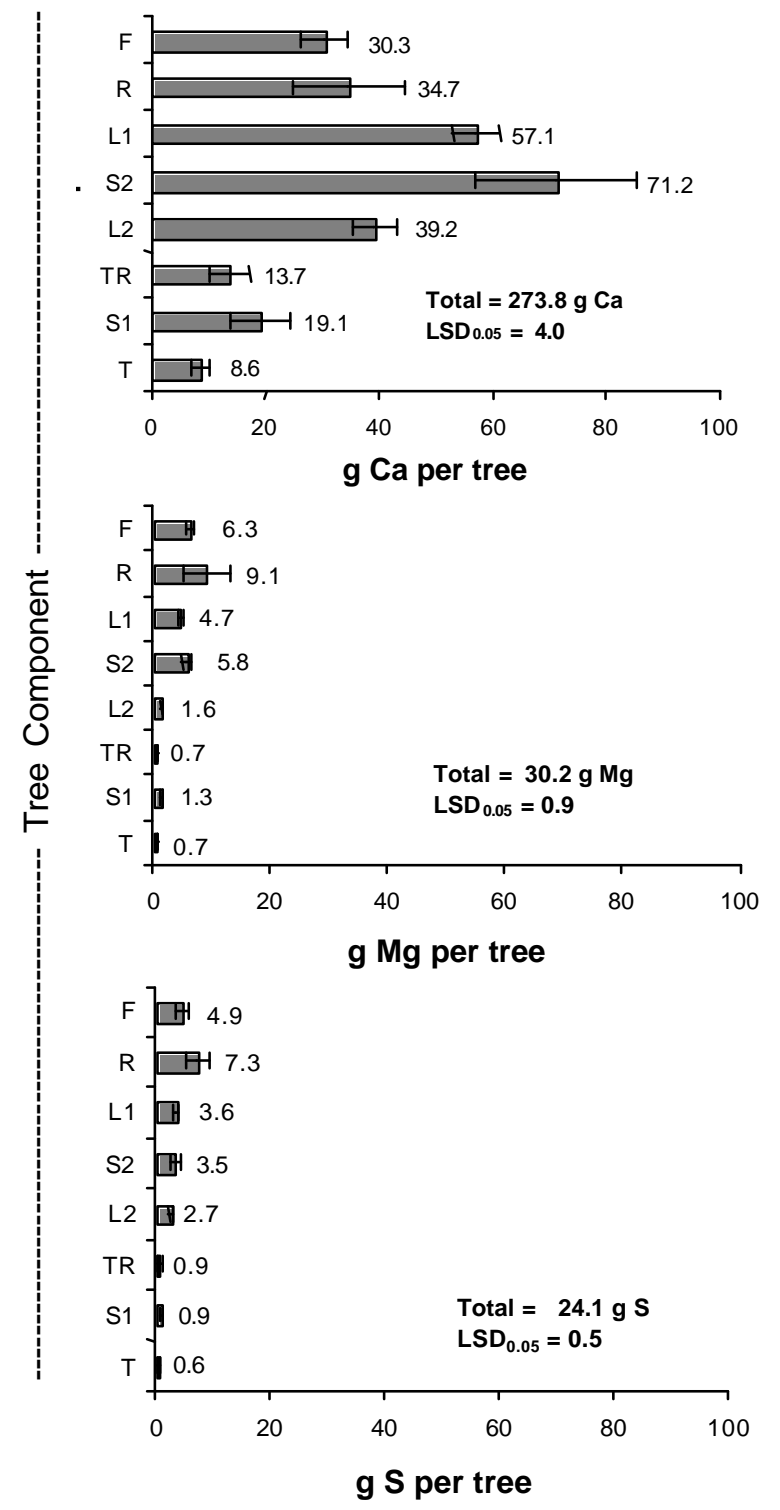

Figure 1 - Macronutrient contents in various parts of 6-year-old Hamlin sweet orange tree on Swingle citrumelo rootstock. Legend: $F=F$ Fuit; $\mathrm{L} 1=$ Leaf $<6$-month-old; $\mathrm{L} 2=$ Leaf $>6$-month-old; $\mathrm{S} 1=$ Twig $>1.5 \mathrm{~cm}$ diameter; $\mathrm{S} 2=$ Twig $<1.5 \mathrm{~cm}$ diameter; $\mathrm{T}=\mathrm{Trunk}$; TR $=$ Taproot; and $\mathrm{R}=$ Roots. $\mathrm{LSD}_{0.05}$ indicates the least significance different among tree biomass components; horizontal bars indicate the standard error of the mean. 
Table 5 - Nutrient contents of 6 -year-old Hamlin sweet orange orchard planted at density of 286 trees per hectare.

\begin{tabular}{|c|c|c|c|c|c|c|c|c|}
\hline \multirow{2}{*}{ Nutrient } & \multicolumn{6}{|c|}{ Nutrient in tree components } & \multirow{2}{*}{ Applied nutrient ${ }^{\dagger}$} & \multirow{2}{*}{ Fruit export } \\
\hline & Leaves & Twigs & Trunk & Fruits & Roots & Total & & \\
\hline & -----------. & 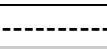 & --.---- & $a^{-1}-----$ & $-\cdots-\cdot-\cdot$ & -------- & $\mathrm{kg} \mathrm{ha}^{-1}$ & $\%$ \\
\hline $\mathrm{N}$ & 17.2 & 11.8 & 2.0 & 18.0 & 17.5 & 66.5 & 65.8 & 27.1 \\
\hline K & 8.7 & 6.9 & 1.4 & 23.2 & 11.8 & 52.0 & 57.2 & 44.6 \\
\hline$P$ & 1.4 & 2.1 & 0.3 & 2.8 & 1.7 & 8.3 & 10.0 & 33.7 \\
\hline $\mathrm{Ca}$ & 27.9 & 25.9 & 2.4 & 8.7 & 13.5 & 78.4 & - & - \\
\hline $\mathrm{Mg}$ & 1.8 & 2.1 & 0.2 & 1.7 & 2.9 & 8.7 & - & - \\
\hline \multirow[t]{2}{*}{$S$} & 1.8 & 1.2 & 0.2 & 1.3 & 2.3 & 6.8 & - & - \\
\hline & 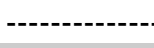 & 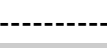 & 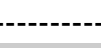 & $a^{-1}-\cdot-\cdot-$ & 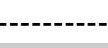 & - & & \\
\hline B & 49 & 30 & 5 & 41 & 40 & 165 & - & - \\
\hline $\mathrm{Cu}$ & 11 & 12 & 3 & 11 & 91 & 128 & - & - \\
\hline $\mathrm{Fe}$ & 65 & 66 & 32 & 61 & 456 & 680 & - & - \\
\hline $\mathrm{Mn}$ & 13 & 5 & 1 & 7 & 184 & 210 & - & - \\
\hline $\mathrm{Zn}$ & 13 & 25 & 13 & 13 & 333 & 397 & - & - \\
\hline
\end{tabular}

${ }^{\dagger}$ Annual fertilization rate; ${ }^{\ddagger}$ Percent of whole tree nutrient content exported by fruits.

Total micronutrients in the orchard accounted for less than $2 \mathrm{~kg} \mathrm{ha}^{-1}$ (Table 5) what is negligible compared to the content of such elements determined in cropped soils. Even though, B plays a striking role on fruit set and production (Chapman, 1968), only a very small amount was determined in vegetative parts of the citrus tree orchard.

\section{REFERENCES}

ALVA, A.K.; FARES, A. A new technique for continuous monitoring of soil moisture content to improve citrus irrigation. Proceedings of Florida State Horticultural Society, v.111, p.113-117, 1998.

ALVA, A.K.; FARES, A.; DOU, H. Dry matter and nitrogen, phosphorus, and potassium partitioning in citrus trees. In: ASA Annual Meeting, Madison, 1999. Abstracts. Salt Lake City, UT, 1999.

AMORÓS CASTAÑER, M. Produccion de agrios. Madri: Grupo MundiPrensa, 1995. 286p.

BATAGLIA, O.C.; RODRIGUEZ, O.; HIROCE, R.; GALLO, J.R.; FURLANI, P.R.; FURLANI, A.M.C. Composição mineral de frutos cítricos na colheita. Bragantia, v.36, p.215-221, 1977.

BATAGLIA, O.C. FURLANI, A.M.C.; TEIXEIRA, J.P.F; FURLANI, PR. GALLO, J.R. Métodos de análise químicas de plantas. Campinas: Instituto Agronômico, 1983. 48p. (Boletim Técnico, 78)

BUSTAN, A.; GOLDSCHMIDT, E.E.; ERNER, Y. Progress in the development of "Citros" - A dynamic model of citrus productivity. Acta Horticulturae, n.499, p.69-80, 1999.

CHAPMAN, H.D. The mineral nutrition of citrus. In: REUTHER, W.; WEBER H.J.; BATCHELOR, L.D. (Ed.) The citrus industry. Riverside: University of California, 1968. v.2, p.127-289.

DASBERG, S. Nitrogen fertilization in citrus orchards. Plant and Soil, v.100, p.1-9. 1987

FARES, A.; ALVA, A.K. Estimation of citrus evapotranspiration by soil water mass balance. Soil Science, v.164, p.302-310, 1999.

FEIGENBAUM, S.; BIELORAI, H.; ERNER, Y.; DASBERG S. The fate of ${ }^{15} \mathrm{~N}$ labeled nitrogen applied to mature citrus trees. Plant and Soil, v.97, p.179 187, 1987.

FERGUSON, J.J.; DAVIES, F.S.; TUCKER, D.P.H.; ALVA, A.K.; WHEATON, T.A. Fertilizer guidelines. In: TUCKER, D.P.H.; ALVA, A.K.; JACKSON, L.K.; WHEATON, T.A. (Ed.) Nutrition of Florida citrus trees. Gainesville: University of Florida, 1995. p.21-25.

HANLON, E.A.; OBREZA, T.A.; ALVA, A.K. Tissue and soil analysis TUCKER, D.P.H.; ALVA, A.K.; JACKSON, L.K.; WHEATON, T.A. (Ed.) Nutrition of Florida citrus trees. Gainesville: University of Florida, 1995. p.13-20.
JACKSON, L.K.; ALVA, A.K.; TUCKER, D.P.H.; CALVERT, D.V. Factors to consider in developing a nutrition program. In: TUCKER, D.P.H.; ALVA A.K.; JACKSON, L.K.; WHEATON, T.A. (Ed.) Nutrition of Florida citrus trees. Gainesville: University of Florida, 1995. p.3-11.

KATO, T. Nitrogen metabolism and utilization in citrus. Horticultural Reviews, v.8, p.181-216, 1986

LEA-COX, J.D.; SYVERTSEN, J.P.; GRAETZ, D.A. Springtime ${ }^{15}$ Nitrogen uptake, partitioning, and leaching losses from young bearing Citrus trees of differing nitrogen status. Journal of the American Society of Horticultural Science, v.126, n.2, p.242-251. 2001.

LEGAZ, F.; SERNA, M.D.; PRIMO-MILLO, E. Mobilization of the reserve N in citrus. Plant and Soil, v.173, p.205-210, 1995

MARSCHNER, H. Mineral nutrition of higher plants. 2.ed. San Diego: Academic Press, 1995. 889p.

MATTOS JR., D. Citrus response functions to N, $\mathrm{P}$, and $\mathrm{K}$ fertilization and $\mathrm{N}$ uptake dynamics. Gainesville, 2000. 133p. Dissertation (Ph.D.) - University of Florida.

MORENO, J.; GARCIA-MARTÍNEZ, L. Nitrogen accumulation in Citrus leaves throughout the annual cycle. Physiologia Plantarum, v.61, p.429-434, 1984.

MULVANEY, R. Mass spectrometry. In: KNOWLES, R.; BLACKBURN, T.H. (Ed.) Nitrogen isotope techniques. San Diego: Academic Press, 1993. p.11-57.

NADIR, M. Partitioning and level of mineral elements in different parts of producing citrus trees. Proceedings of the International Society of Citriculture, v.1, p.193-205, 1973.

NATIONAL COOPERATIVE SOIL SER VICE. Soil survey of Polky county, Florida. Gainesville: United States Department of Agriculture and University of Florida, 1990. 235p.

QUAGGIO, J.A.; RAIJ, B. van; TOLEDO PIZA, JR., C. Frutíferas. In: RAIJ, B. van; CANTARELLA, H.; QUAGGIO, J.A.; FURLANI, A.M.C. (Ed.) Recomendações de adubação e calagem para o estado de São Paulo. 2.ed. Campinas: Instituto Agronômico \& Fundação IAC, 1996. p.121-153.

SAS INSTITUTE. The SAS System - Release 6.12. Cary: SAS Institute. 1996. SMITH, P.F. Citrus nutrition. In: CHILDERS, N.F. (Ed.) Temperate to tropical fruit nutrition. 2.ed. Somerville: Somerset Press, 1966a. p.174-207.

SMITH, P.F. Leaf Analysis of Citrus. In: CHILDERS, N.F. (Ed.) Temperate to tropical fruit nutrition. 2.ed. Somerville: Somerset Press, 1966b. p.208 228

SMITH, P.F.; REUTHER, W.; SPECHT, A.W.; HRNCIAR, G. Effect of differential nitrogen, potassium, and magnesium supply to young Valencia orange trees in sand culture on mineral composition especially of leaves and fibrous roots. Plant Physiology, v.29, p.349-355, 1954.

WUTSCHER, H.K. Comparison of soil, leaf and feeder root nutrient levels in the citrus blight-free and citrus blight-affected areas of a 'Hamlin' orange grove. Proceedings of the Florida State Horticultural Society, v.99, p.74-77, 1986.

Received December 7, 2001 